\title{
基于 Gogny 相互作用的壳模型计算
}

\author{
蒋炜光, 胡柏山, 许甫荣* \\ 北京大学物理学院, 北京 100871 \\ *联系人, E-mail: frxu@pku.edu.cn \\ 2017-03-09 收稿, 2017-04-21 修回, 2017-04-21 接受, 2017-05-18 网络版发表 \\ 国家自然科学基金(11235001, 11320101004, 11575007)资助
}

\begin{abstract}
摘要 在壳模型的框架下引入了密度依赖的Gogny相互作用以研究有限核的核结构性质。文中详细地讨论了密 度依赖核力的性质和在壳模型中的运用。通过迭代求解的方法可以得到任意模型空间下的两体矩阵元和单粒子 能. 经过 $p$ 壳和 $s d$ 壳的计算我们发现Gogny相互作用可以在跨度较大的核区内有效计算能谱和结合能等核结构信 息. 并且在各套Gogny参数中 D $1 S$ 的表现最好, 与实验数据进行对比能给出很好的计算结果.
\end{abstract}

关键词壳模型, 有效相互作用, Gogny 力, 两体矩阵元, 单粒子能

壳模型作为描述原子核结构的一个强而有效的 工具正广泛应用在有限核的计算当中. 利用壳模型 处理核结构问题时大家面对的一个重要挑战是如何 在截断的模型空间内构建有效哈密顿量. 显然我们 可以从现实核力出发, 运用恰当的微扰理论来导出 有效哈密顿量 ${ }^{[1]}$. 然而这样的计算相对而言比较复 杂, 如果追求精确的定量描述则需要高阶的修正(例 如三体力, three-nucleon force, 3NF). 一旦引入高阶 修正后, 整个计算的影响因素将会增多, 数值上的稳 定性会下降, 而且整个模型的计算维数会急速增长.

另一方面, 也可以使用经验的两体矩阵元 (two body matrix elements, TBMEs)来进行壳模型计算, 这 样可以降低计算量而且在大多数情况下得到更好的 定量结果. 一般而言在经验模型中, 在现实核力矩阵 元的基础上通过拟合核结构的实验数据(主要是结合 能和能谱)对矩阵元进行优化调整, 最后得到适用的 经验两体矩阵元. 针对不同的模型空间, 目前已经有 很多广泛应用的经验哈密顿量, 例如 $p$ 壳中的PWT相 互作用 ${ }^{[2]}, s d$ 壳中的 USD相互作用 ${ }^{[3,4]}, p f$ 壳中的 GXPF1相互作用 ${ }^{[5]}$. 对于这样的相互作用可以认为
其通过拟合参数已经等效地含括了高阶的修正效应 (三体力等). 但是这样的拟合过程对于两体矩阵元数 目庞大的情况是十分困难的. $s d$ 壳中的USD相互作用 力一共有 63 个 TBMEs 外加 3 个单粒子能 (singleparticle energies, SPEs) 需要拟合, 而到了 $p f$ 壳中 GXPF1相互作用就包含了 195 个 TBMEs 和 4 个 SPEs. 其中部分的 TBMEs(尤其是非对角元，off-diagonal matrix element)对于拟合是不敏感的, 这给TBMEs的 获得带来了很大的不确定性. 对于跨壳(cross shell) 的情况，模型空间里包含了两个或更多的主壳，此时 拟合过程会变得更加困难. 这不仅是因为需要拟合 的TBMEs的数目变得更加庞大了, 而且也因为跨壳 情况下实验的SPEs很不容易获得. 从实验能谱上, 很难区分核心的集体激发和单粒子激发所产生的能 级，而后者正是实验SPEs的来源.

除了上述的方法, 还可以通过唯象的相互作用 来导出有效哈密顿量. 举个例子, $\delta$ 形式的唯象相互 作用(delta-type phenomenological interaction)已经被 应用在壳模型的计算当中，像表面 $\delta$ 势 (surface delta interaction)和Skyme势 ${ }^{[6,7]}$. 当前的工作中, 采用了有 
限程的Gogny ${ }^{[8]}$ 来计算有效TBMEs和SPEs. Gogny 相互作用一共包含了 14 个参数. 现在已经有好几套 通过平均场计算 (具体而言是 Hartree-Fock-Bogolyubov方法) 拟合核结构数据从而得到的 Gogny 参 数 ${ }^{[8 \sim 10]}$. 目前的壳模型计算中, 为了检验模型的效用 和观察相互作用在核子数 $A$ 跨度较大的区域内的表 现, 我们采用的是已有的 Gogny参数而没有重新拟 合. 如果采用拟合参数的方法, 可以进一步改善 Gogny力在某确定大小的模型空间内的数值计算结 果, 目前参数拟合不在本文的讨论范围之内. 采用唯 象核力的另一个优点是, 可以跨壳地计算 TBMEs 和 SPEs, 而这对于经验方法和基于现实核力的方法而言 很困难. 另外Gogny力和Skyrme力已经广泛而且成功 地运用在平均场的计算当中, 并且能对诸如结合能 (binding energies, BE), 电荷半径 (charge radi)和饱和 密度(saturation desities)这些性质给出很好的描述. 在 本文的末尾使用Gogny相互作用计算了 $\mathrm{O}$ 链的基态能 量, 得到了与实验相符的趋势并重复了其中子滴线.

\section{1 基于Gongy 力的有效哈密顿量}

对于包含冻结核心(frozen core)的壳模型, 有效 哈密顿量可以写成一系列的单体和两体算符之 和 $^{[3,11]}$,

$$
H=\sum_{a} e_{a} \hat{n}_{a}+\sum_{a \leqslant b, c \leqslant d} \sum_{J T} V_{J T}(a b ; c d) \hat{T}_{J T}(a b ; c d),
$$

这里的 $e_{a}$ 和 $\hat{n}_{a}$ 分别表示单粒子轨道的能量和单粒子 轨道的粒子数算符, 下标 $a$ 代表着 $n_{a}, l_{a}, j_{a}$ 这一套量 子数. 其中的

$$
\hat{T}_{J T}(a b ; c d)=\sum_{J_{z} T_{z}} A_{J J_{z} T T_{z}}^{\dagger}(a b) A_{J J_{z} T T_{z}}(c d),
$$

则是连接核子对 $a, b$ 和 $c, d$ 的两体密度算符, 并有着相 对应的角动量 $J$ 和同位旋 $T . A_{J J_{z} T T_{z}}^{+}$和 $A_{J J_{z} T T_{z}}$ 是核子对 的产生和湮灭算符. 对于壳模型而言, 得到公式(2) 中的两体矩阵元 $V_{J T}(a b ; c d)=a, b\left|V_{N N, 12}\right| c, d$ 是关键的 步骤. 正如之前所述, 在当前工作中采用的是如下形 式的有限程Gogny相互作用:

$$
\begin{aligned}
V_{N N, 12}= & \sum_{i=1}^{2} e^{-\left(\vec{r}_{1}-\vec{r}_{2}\right)^{2} / \mu_{i}^{2}}\left(W_{i}+B_{i} P^{\sigma}-H_{i} P^{\tau}-M_{i} P^{\sigma} P^{\tau}\right) \\
& +t_{3} \delta\left(\vec{r}_{1}-\vec{r}_{2}\right)\left(1+x_{0} P^{\sigma}\right)\left[\rho\left(\frac{\vec{r}_{1}+\vec{r}_{2}}{2}\right)\right]^{\alpha} \\
& +i W_{0} \delta\left(\vec{r}_{1}-\vec{r}_{2}\right) \delta\left(\vec{\sigma}_{1}+\vec{\sigma}_{2}\right) \cdot \vec{k}^{\prime} \times \vec{k} .
\end{aligned}
$$

这里的 $P^{\sigma}=1 / 2\left(1+\vec{\sigma}_{1} \cdot \vec{\sigma}_{2}\right)$ 和 $P^{\tau}=1 / 2\left(1+\vec{\tau}_{1} \cdot \vec{\tau}_{2}\right)$ 分别 是自旋和同位旋交换算符, 其中 $\vec{\sigma}_{i}$ 和 $\vec{\tau}_{i}$ 则分别是自 旋和同位旋矩阵矢量. $\rho$ 是原子核在当前位置的密度. 高斯项中的 $\mu_{i}=0.7$ 和 $1.2(\mathrm{fm})$ 分别模拟核力的两种力 程, 总体效应是在两核子间提供吸引的相互作用. 第 二项是密度依赖项(density-dependent term), 源自于 三体修正，效应是为两核子产生恰当的排斥作用. 最 后一项是简单的自旋轨道耦合 (spin-orbit coupling), 其中 $\vec{k}=\left(\vec{\nabla}_{1}-\vec{\nabla}_{2}\right) / 2 i$ 是作用在右矢上的两核子相对 波矢算符, $\overrightarrow{k^{\prime}}$ 则是作用在左矢上的波矢算符.

由于Gogny 力是写在相对运动坐标(relative coordinate) $\left(\vec{r}_{1}-\vec{r}_{2}\right)$ 和质心坐标 (center-of-mass coordinate) $\left(\vec{r}_{1}+\vec{r}_{2}\right)$ 下的, 因此很自然地可以在相对系和质心系 下推导其两体矩阵元. 首先, 需要通过下面的 Moshinsky变换来得到实验室系下的矩阵元,

$$
\begin{aligned}
& \left|\left(n_{a} l_{a} m_{a}\right)\left(n_{b} l_{b} m_{b}\right) \lambda \mu\right\rangle \\
& =\sum_{n l N L} M_{\lambda}\left(n l N L ; n_{a} l_{a} n_{b} l_{b}\right)|(n l m)(N L M) \lambda \mu\rangle,
\end{aligned}
$$

其中 $\lambda$ 表示总的轨道角动量, 而 $\mu$ 表示总轨道角动量 的 $z$ 方向上的分量. $M_{\lambda}\left(n l N L ; n_{a} l_{a} n_{b} l_{b}\right)$ 则是被称为 Moshinsky括号 ${ }^{[12,13]}$ 的转换系数. 这一变换把 $a, b$ 两个 独立的谐振子(harmonic osillator, $\mathrm{HO}$ )的波函数与 $\mathrm{HO}$ 的相对运动 $(n l m)$ 和质心运动 $(N L M)$ 波函数联系在一 起. 凭借着这个变换, 实验室系下的具有好量子数 $\left(J J_{z} T\right)$ 的两体波函数可以写成下面的形式

$$
\begin{aligned}
& \left|\left(n_{a} l_{a} m_{a}\right)\left(n_{b} l_{b} m_{b}\right) J J_{z} T\right\rangle \\
= & \sum_{n l N L m M} \sum_{\mu S_{z}} \sum_{\lambda S}\left\{\begin{array}{ccc}
l_{a} & 1 / 2 & j_{a} \\
l_{b} & 1 / 2 & j_{b} \\
\lambda & S & J
\end{array}\right\} \frac{1-(-1)^{S+T+l}}{\sqrt{2\left(1+\delta_{n_{a} n_{b}} \delta_{l_{a} l_{b}} \delta_{j_{a} j_{b}}\right)}} \\
& \times M_{\lambda}\left(n l N L ; n_{a} l_{a} n_{b} l_{b}\right) \hat{j_{a}} \hat{j_{b}} \hat{S} \hat{\lambda}\langle\operatorname{lmLM} \mid \lambda \mu\rangle\left\langle\lambda \mu S S_{z} \mid J J_{z}\right\rangle \\
& \times|n l m\rangle|N L M\rangle\left|X_{S S_{z}}\right\rangle|T\rangle,
\end{aligned}
$$

其中 $J$ 和 $J_{z}$ 分别是总的角动量和其三分量, $T$ 是总的同 位旋, $S$ 是总的自旋角动量而 $S_{z}$ 是其三分量. 上面所用 到的所有符号均使用标准写法 ${ }^{[14,15]}$, 其中包含了 $9 j$ 系 数和Clebsch-Gordan系数. 现在通过公式(5)可以把自 旋波函数同位旋波函数与空间部分的波函数分离开 来, 并且把空间部分转换成HO的质心运动和相对运 动两部分. 结合公式(3)和公式(5), 基于 Gogny相互 作用的两体矩阵元

$V_{J T}(a b ; c d)=\left\langle\left(n_{a} l_{a} j_{a}\right)\left(n_{b} l_{b} j_{b}\right) J T|V|\left(n_{c} l_{c} j_{c}\right)\left(n_{d} l_{d} j_{d}\right) J T\right\rangle$ 
就可以解析地求解出来. 这里省略了量子数 $J_{z}$ 因为 TBMEs对于不同的 $J_{z}$ 而言是简并的. 为了说明如何 得到Gogny相互作用的矩阵元, 下面将针对其高斯项 进行简单的推导.

由公式(3)可知 Gogny力的高斯项只显含相对坐 标 $\vec{r}=\vec{r}_{1}-\vec{r}_{1}$ 、自旋和同位旋交换算符, 因此在计算 TBMEs 时只需要考虑包含特定成分的波函数 $\left\langle n^{\prime} l^{\prime} m^{\prime} S^{\prime} S_{z}^{\prime} T^{\prime}|V| n l m S S_{z} T\right\rangle$ 即可, 其他部分只是单纯的 系数乘积或者是有着正交关系的波函数. 对于三维 的情况(使用极坐标 $r, \theta, \phi$ ) 在相对坐标系下有如下的 关系:

$\left\langle n^{\prime} l^{\prime} m^{\prime} S^{\prime} S_{z}^{\prime} T|V| n l m S S_{z} T\right\rangle$

$=\iiint r^{2} \sin \theta\left\langle n^{\prime} l^{\prime} m^{\prime} S^{\prime} S_{z}^{\prime} T^{\prime} \mid \vec{r}\right\rangle V\left\langle\vec{r} \mid n l m S S_{z} T\right\rangle \mathrm{d} r \mathrm{~d} \theta \mathrm{d} \phi$.
为了计算矩阵元, 还需要坐标空间下的 $\mathrm{HO}$ 波函数,

$$
\begin{aligned}
& \langle\vec{r} \mid n l m\rangle=R_{n l} Y_{l m}(\hat{r}) \\
& =\sqrt{\frac{2^{l-n+2}(2 v)^{l+1.5}(2 l+2 n+1) ! !}{\sqrt{\pi}[(2 l+1) ! !]^{2} n !}} r^{l} \mathrm{e}^{-v r^{2}} \\
& \times \sum_{x=0}^{n}(-1)^{x} 2^{x} \frac{n !(2 l+1) ! !}{x !(n-x) !(2 l+2 x+1) ! !}\left(2 v r^{2}\right)^{x} Y_{l m}(\hat{r}),
\end{aligned}
$$

这里的 $R_{n l}$ 是 $\mathrm{HO}$ 波函数的径向部分, 而 $Y_{l m}(\hat{r})$ 则是角 向部分. $\hat{r}$ 是 $\vec{r}$ 的单位向量, $r=|\vec{r}| . v=\mu \omega / 2 \hbar$ 是谐 振子的长度参数(size parameter), $\mu$ 是约化质量(在相对 系下 $\mu=m / 2$ ). 对于球形谐振子还有如下的正交关系:

$$
\iint \sin \theta Y_{l^{\prime} m^{\prime}}^{*}\left(\hat{r}^{\prime}\right) Y_{l m}(\hat{r}) \mathrm{d} \theta \mathrm{d} \phi=\delta_{l^{\prime} l} \delta_{m^{\prime} m} .
$$

由公式(3), (6) (8)可以得到

$$
\begin{aligned}
& \left\langle n^{\prime} l^{\prime} m^{\prime} S^{\prime} S_{z}^{\prime} T|V| n l m S S_{z} T\right\rangle \\
& =\delta_{l^{\prime} l^{\prime}} \delta_{m^{\prime} m} \delta_{S^{\prime} S} \delta_{T^{\prime} T} \sum_{i=1}^{2} \sum_{x=0}^{n^{\prime}} \sum_{y=0}^{n} \times \sqrt{2^{2 l^{\prime}-n^{\prime}+3.5} v^{l^{\prime}+1.5}\left(2 l^{\prime}+2 n^{\prime}+1\right) ! ! n^{\prime} !} \sqrt{2^{2 l-n+3.5} v^{l+1.5}(2 l+2 n+1) ! ! n !} \\
& \times(-1)^{x+y} 2^{-l^{\prime}-2+x+y} \frac{1}{\left(n^{\prime}-x\right) ! x !} \frac{1}{(n-y) ! y !\left(2 l^{\prime}+2 x+1\right) ! !} \frac{1}{(2 l+2 y+1) ! !} \\
& \times\left(2 v+\frac{1}{\mu_{i}^{2}}\right)^{-x-y-l^{\prime}-1.5}\left(2 x+2 y+2 l^{\prime}+1\right) ! ! \\
& \times\left[W_{i}+B_{i}\left(S^{2}+S-1\right)-H_{i}\left(T^{2}+T-1\right)-M_{i}\left(S^{2}+S-1\right)\left(T^{2}+T-1\right)\right] .
\end{aligned}
$$

通过相似的推导可以得到Gogny相互作用下完整的 TBMEs. 得出的结果已和分波法 (partial-wave decomposition) ${ }^{[16]}$ 得到的结果相比较 (到 $L=4$ 阶), 符合程度 令人满意.

把密度依赖的相互作用引人壳模型是一件值得 仔细推敲的事情. 早期的一些在壳模型中引人密度 依赖力的工作是由 Sagawa等人 ${ }^{[7]}$ 和 Gomez等人 ${ }^{[17]}$ 利 用Skyrme力做的一些尝试. 当采用的核力有密度依 赖时, 必然会面对下面的困难. 首先, 壳模型不仅需 要关注核的基态还要考虑核的激发态, 每个这样的 态有着各自相应的密度. 而在计算中如果要求每一 个态都有着各自独立的密度分布会对计算带来很多 不必要的困难(比如收玫性的问题). 另一方面在计算 出相应哈密顿量下组态混合的本征态之前无法确定 核的密度分布. 而为了解出本征态又需要得到相互 作用的准确形式, 亦即需要知道核的密度分布. 对于 前者, 考虑到激发态的密度分布与基态的密度分布 区别很小, 其实并不需要每个态都定一个独立的密
度. 实际在大多数情况下, 对于稳定核的低激发态可 以采用基态密度分布作为有效的近似. 对于后者, 这 样的一个循环的问题明显和解Hartree-Fock方程时遇 到的一样 ${ }^{[18]}$. 由于核力的密度依赖性, 需要进行迭 代计算. 为了加速迭代计算的收敛从谐振子单粒子 波函数出发, 把单粒子波函数填充到能量最低的位 置(填到费米面), 然后把这一组单粒子组成的波函数 作为试探波函数来得到初始的密度, 从而得到 TBMEs. 有了 TBMEs就可以通过在当前模型空间下 对角化来解出该哈密顿量下的第一次近似解. 然后 把解出的基态密度当做哈密顿量的新输人重复上述 操作最终得到收玫的结果. 计算结果表明不同的初 始密度分布在迭代后总会收敛到相同的结果。唯一 的区别是当选取的试探波函数越接近体系“真实”的 波函数时, 迭代计算的次数会越少.

在确定的模型空间下进行壳模型计算时, 部分 相互作用使用的有效 TBMEs是常数(不随核子数 $A$ 变 化), 例如 Cohen 和 Kurath 提出的 $p$ 壳中的 CK相互作 
用 ${ }^{[19]}$. 另外也有一些相互作用采用的是随核子数变 化的矩阵元形式, 像 $s d$ 区的USD相互作用在矩阵元 前就有着 $(18 / A)^{0.3}$ 这一系数 ${ }^{[4]}$. 而在本文的模型中由 于哈密顿量取决于 $\mathrm{HO}$ 的径向波函数亦即 $\hbar \omega$, 因此对 于不同的核子数 $A$ 需要计算不同的 TBMEs.

有核心的壳模型计算中, 除了 TBMEs之外还需 要SPEs作为额外的输人参数. 对于大部分的有效相 互作用, SPEs是通过和TBMEs一同拟合实验数据得 到的, 又或者是直接取实验的单粒子能. 但是当面对 跨壳或者重核问题的时候, 单粒子能的获得将会变 得更加困难. 原因一是因为跨壳拟合的计算代价巨 大, 二是因为跨壳时单粒子激发容易被核心的集体 激发态所淹没因此很难得到实验单粒子能. 当前的 计算中采用的SPEs如下,

$$
e_{j}=t_{j}+\frac{1}{2(2 j+1)} \sum_{j} \sum_{J T}(2 J+1)(2 T+1)\left\langle j j^{\prime} J T|V| j j^{\prime} J T\right\rangle,
$$

这里 $j$ 代表着价壳轨道, $j^{\prime}$ 代表着核心的轨道. 当前 采用的SPE为价壳核子的动能和其与核心内所有核 子的相互作用之和. 需要注意的是这里的SPEs与 TBMEs是由相同的Gogny相互作用计算得出, 同样 依赖于核子数 $A$. 之前曾经提到可以采用实验的单粒 子能并期望得到定量上更好的结果. 然而由于进行 的是组态混合壳模型计算, 因此当考虑的组态足够 多时候总能抹平采用不同单粒子能所产生的影响.

另一个采用公式(10)作为计算单粒子能的方法 是为了得到一个更自洽的计算开壳核结合能的方法. 一般而言结合能是由价壳粒子的能量和核心能量求 和而得到. 通常对于有效相互作用而言核心能量都 假设为常数而且一般取的实验值. 例如对于 $s d$ 壳, 在 计算结合能时要加上核心 ${ }^{16} \mathrm{O}$ 的结合能 $127.6 \mathrm{MeV}^{[20]}$. 但是当我们希望更自洽的得到结合能时, 核心能量 为常数这一假设是不恰当的, 特别是在一个较大的 核区进行计算(跨壳). 当前的计算中采用相同的核力 来计算价壳能量和核心的能量. 核心能量可以表示为

$$
E_{c}=T_{c}+V_{c},
$$

其中

$$
T_{c}=\sum_{k_{a}}(2 T+1)(2 J+1)\left\langle k_{a}|\hat{T}| k_{a}\right\rangle,
$$

而 $V_{c}$ 则是

$$
V_{c}=\sum_{k_{a} \leqslant k_{b}} \sum_{J T}(2 T+1)(2 J+1)\left\langle k_{a} k_{b} J T|V| k_{a} k_{b} J T\right\rangle .
$$

这里的 $k_{a}$ 和 $k_{b}$ 代表闭壳中的轨道, 而 $T_{c}$ 和 $V_{c}$ 分别是核 心的动能和势能. 这里的 $V$ 取的是和计算TBMEs时一 样的Gogny相互作用. 现在可以看出价壳和核心的能 量都与谐振子波函数有关，因此原子核的结合能可 以看做一个以谐振子长度 $\hbar \omega$ 为变量的方程. 为了避 免引人额外的自由参数, 应当选取结合能随 $\hbar \omega$ 变化 曲线上能量最低点作为 $\hbar \omega$ 的值. 这一选择所定出的 谐振子长度和经验公式 $\left(\hbar \omega=45 A^{-1 / 3}-25 A^{-2 / 3}\right)$ 给出 的值几乎是一致(例如对于 $A=20$ 的情况两者的差别为 0.38 ). 两种 $\hbar \omega$ 的选取方式对于基态能量几乎没有影 响, 这是由于结合能随 $\hbar \omega$ 变化的曲线最低点附近斜 率较小所致.

\section{2 两体矩阵元}

为了测试Gogny相互作用是否能在壳模型框架 下正确描述核子间相互作用，可以取其TBMEs和别 的有效相互作用的结果进行对比. 经过大量的计算 表明所有 Gogny参数中D1S ${ }^{[9]}$ 的表现最好(参数的定义 见表1). 以下所有 Gogny力的计算中均使用的D1S这 套参数与其他常用的有效相互作用的结果进行比较.

首先在 $p$ 壳, 把 $\mathrm{D} 1 \mathrm{~S}$ 的矩阵元与 $\mathrm{PWT}^{[2]}$ 的和 $\mathrm{HM}^{[20]}$ 的进行对比. 图1展示了D1S, PWT和HM在 $p$ 壳 的 15 个两体矩阵元, 图中 abcd表示轨道编号, $1=p_{1 / 2}$, $3=p_{3 / 2}$. Gogny和PWT的矩阵元均取 $A=12$ 时的值. 另 外为了便于对比, 矩阵元根据同位旋分为 $T=1$ 和 $T=0$ 两组. 由图 1 可以很明显地看出三种相互作用的矩阵 元在不同的 $T$ 分道上趋势上都是一致的.

然后在 $s d$ 壳, 把D1S相互作用得到的63个TBMEs 与 $\mathrm{USDB}^{[4]}$ 和RGSD ${ }^{[22]}$ 对比, 对比结果如图 2 所示. 需 要注意的是D1S 和USDB相互作用的矩阵元有质量数

表 1 Gogny参数D1S 的定义 ${ }^{[9]}$

Table 1 The values of the parameters for Gogny D1S

\begin{tabular}{ccccccccc}
\hline$\mu(\mathrm{fm})$ & $W(\mathrm{MeV})$ & $B(\mathrm{MeV})$ & $H(\mathrm{MeV})$ & $M(\mathrm{MeV})$ & $W_{0}(\mathrm{MeV})$ & $t_{3}(\mathrm{MeV})$ & $x_{0}$ & $\alpha$ \\
\hline 0.7 & -1720.30 & 1300.00 & -1813.53 & 1397.60 & \multirow{2}{*}{130} & 1390.60 & 1 \\
1.2 & 103.64 & -163.48 & 162.81 & -223.93 & & & $1 / 3$ \\
\hline
\end{tabular}




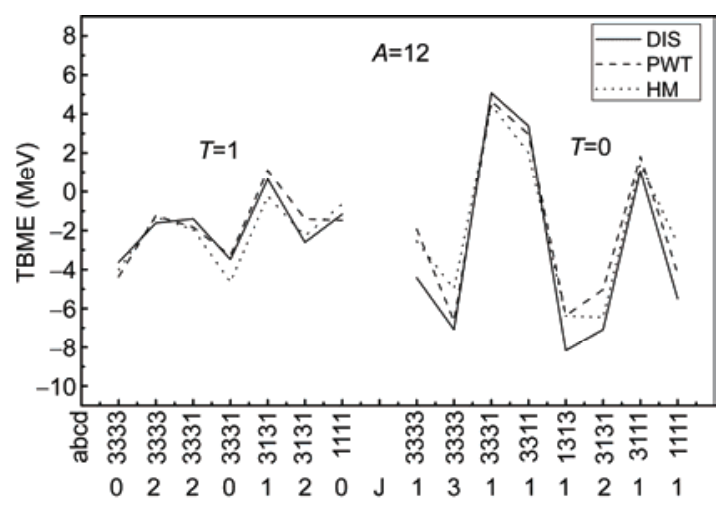

图 1 D1S, PWT和HM相互作用矩阵元对比, 其中abcd表示轨道编 号, $1=p_{1 / 2}, 3=p_{3 / 2}$

Figure 1 Comparison of D1S, PWT and HM interaction TBMEs. In the abcd labels, 1 means $p_{1 / 2}$ and 3 means $p_{3 / 2}$

依赖而RGSD与 $A$ 无关. 图中, D1S和USDB的矩阵元 都取的是 $A=18$ 时的值. 通过图 2和分析计算可以知道 D1S 相互作用得出的矩阵元与 USDB和RGSD的矩阵 元相似. 其中与 USDB 和 RGSD的矩阵元的均方根 (root mean square, rms) 分别为 0.86 和 $0.84 \mathrm{MeV}$.

\section{Gogny相互作用在不同核区的应用}

如前文所述, 在当前的模型下可以得到Gogny相 互作用在不同核区的TBMEs和SPEs, 并且能根据它 们进行组态混合壳模型计算. 原则上来讲Gogny相互 作用在拟合时考虑了从轻核一直到重核的结合能数 据, 在平均场的计算中可以适用于大跨度核区的计 算. 为了测试Gogny相互作用在壳模型中是否能保持 这一优点, 初步计算了 $p$ 区和 $s d$ 区的原子核, 以观察
在 $A$ 跨度多个核区时Gogny相互作用的表现.

对于 $p$ 区我们选择了 ${ }^{7} \mathrm{Li},{ }^{10} \mathrm{Be},{ }^{11} \mathrm{~B}$ 三个接近 $N=Z$ 的核作为例子展示 D1S 相互作用的描述水平. 图3显 示的是D1S相互作用的计算结果, 同时放人了 PWT 相互作用和实验的能谱以作比较. 从图中可以看出 D1S相互作用可以很好地描述这几个核的低激发能 谱, 与实验和PWT的结果都符合得很好.

而在 $s d$ 区, 我们计算了 $\mathrm{O}$ 链的一系列能谱以确定 $\mathrm{D} 1 \mathrm{~S}$ 相互作用是否在 $s d$ 区继续适用. 从图4中可以看 出除了 ${ }^{19} \mathrm{O}$ 的 $9 / 2+$ 和 $1 / 2+$ 两条能级反转了以外, 其他 的包括基态自旋宇称, 能级顺序都与实验符合得很 好. 而 ${ }^{19} \mathrm{O}$ 能级反转的问题主要是由于单粒子能的原 因. 计算 ${ }^{19} \mathrm{O}$ 时, $\mathrm{D} 1 \mathrm{~S}$ 的单粒子能是 $-7.23,-5.09$ 和 0.26 , 分别对应着 $d_{5 / 2}, s_{1 / 2}$ 和 $d_{3 / 2}$ 三条轨道, 而实验的单粒子 能则是 $-4.14,-3.27$ 和 $0.94^{[20]}$. 而对于偶 $A$ 核而言, 能 谱结构受单粒子态影响很大.

然而单粒子能与实验的误差所带来的能谱误差 会随着价核子数增加而降低, 实际上在组态数目足 够多的情况下, 多组态混合总能补偿单粒子能不同 带来的影响. 例如计算 ${ }^{21} \mathrm{O}$ 的时候单粒子能的误差仍 然存在, 但是这一误差对能谱的影响已经被组态混 合所降低, 能谱也已经和实验符合得相当好.

如前面提到, 当前的模型可以更自洽的计算原 子核的结合能而不需要引人额外的核心能量 (core energy)作为参数. 图 5 中显示的是利用D1S相互作用 计算的氧同位素链的结合能, 同时给出了实验的结 合能曲线作为对比.

可以看出在 $N=16$ 之前结合能曲线与实验符合得

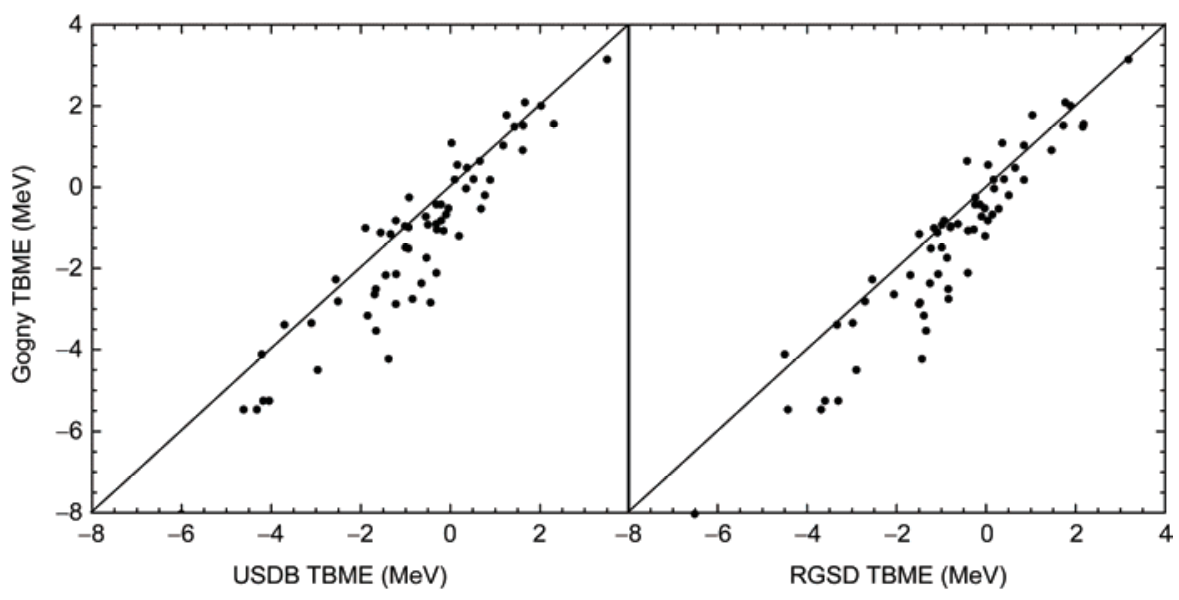

图 2 D1S, USDB和RGSD相互作用矩阵元对比

Figure 2 Comparison of D1S, USDB and RGSD TBMEs 


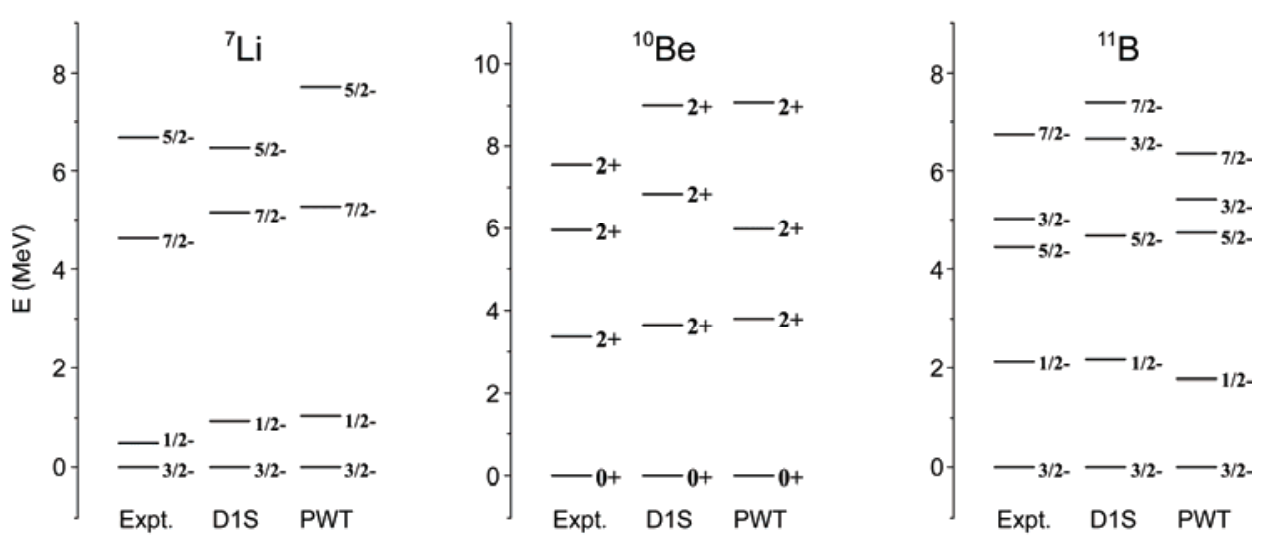

图 3 D $1 S$ 相互作用计算 ${ }^{7} \mathrm{Li},{ }^{10} \mathrm{Be},{ }^{11} \mathrm{~B}$ 的能谱, 与PWT相互作用和实验相对比, 实验数据源自参考文献[20]

Figure 3 Energy levels for ${ }^{7} \mathrm{Li},{ }^{10} \mathrm{Be},{ }^{11} \mathrm{~B}$ calculated by D1S and PWT, compared with experimental data ${ }^{[20]}$

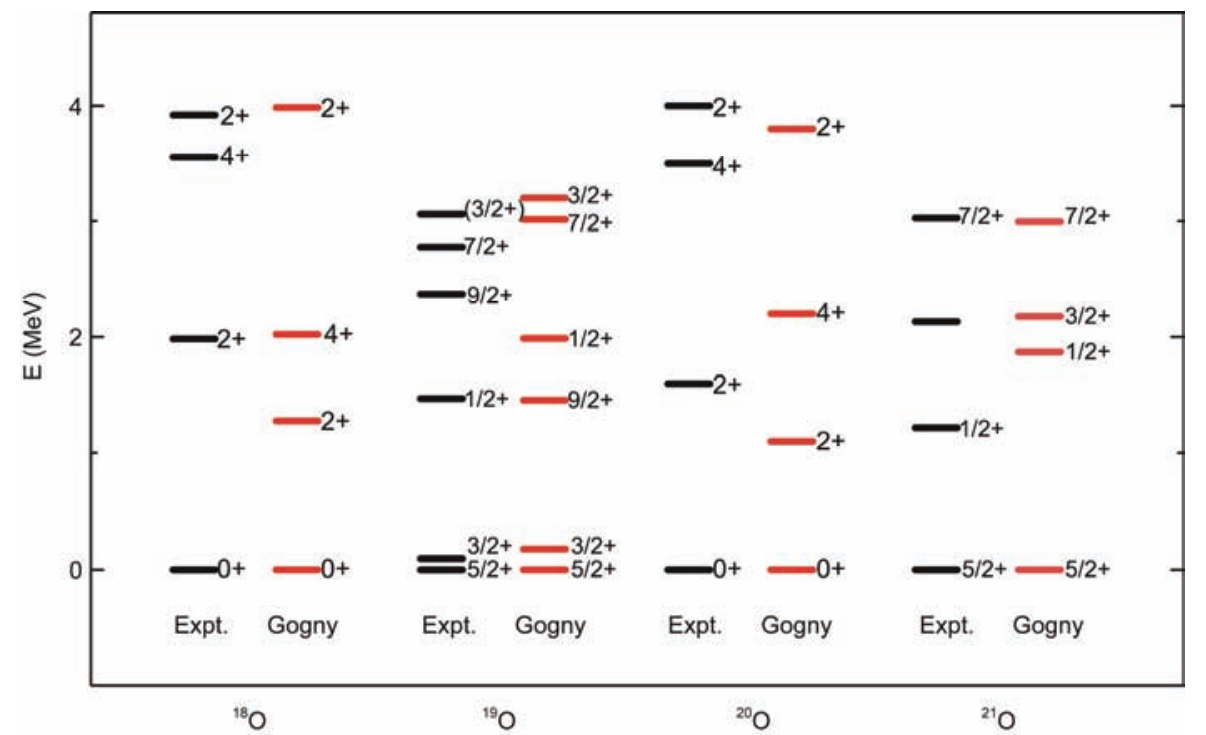

图 4 (网络版彩色)D1S相互作用计算的 ${ }^{18-21} \mathrm{O}$ 能谱, 实验数据源自参考文献[20]

Figure 4 (Color online) Energy levels for ${ }^{18-21} \mathrm{O}$ obtained by D1S, compared with experimental data ${ }^{[20]}$

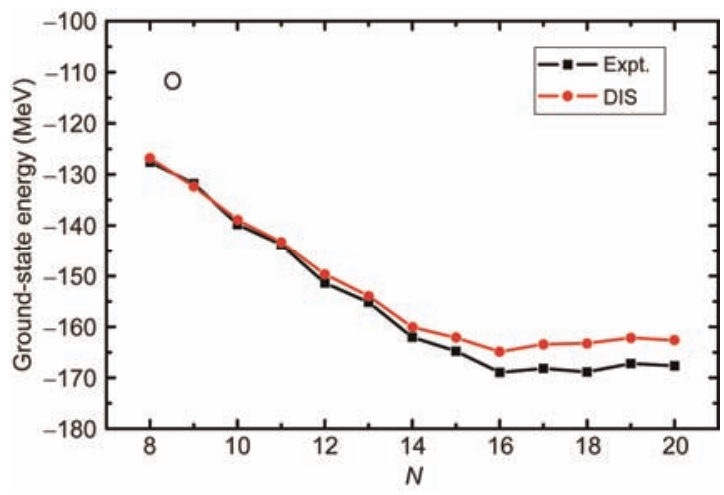

图 5 (网络版彩色)D1S相互作用计算的 $\mathrm{O}$ 链的结合能曲线, 实验数 据源自参考文献[20]

Figure 5 (Color online) Ground-state energies of oxygen isotopes, compared with experimental data ${ }^{[20]}$
相当好. ${ }^{25} \mathrm{O}$ 是氧同位素中第一个不约束的核, 而我 们的计算正确重复了氧链的中子滴线(drip line), 虽 然在滴线之后由于 $s d$ 模型空间的限制我们的计算结 果比实验的更高, 但是D1S相互作用仍然正确的重复 了结合能的趋势, 并给出了 ${ }^{26} \mathrm{O}$ 单中子约束, 双中子 不约束的结论.

\section{4 结论}

当前工作中在壳模型的框架下引人了Gogny相 互作用进行核结构计算. 文章中讨论了密度依赖相 互作用的性质并给出了组态混合壳模型下 Gogny力 的TBMEs和SPEs的计算方法. 基于密度依赖相互作 
用的特性我们提出了迭代的壳模型计算方法, 并完 成了收玫性检验. 通过该模型我们可以用统一的相 互作用来计算较大核区内原子核的各种性质(结合 能、能谱等). 为了检验Gogny相互作用在不同核区中 的表现, 我们给出了 $p$ 壳、 $s d$ 壳的矩阵元对比, 举出了 $p$ 区和 $s d$ 区中数个核的能谱作为例子, 并且计算了 $\mathrm{O}$ 链的结合能曲线. 这些结果表明Gogny形式的唯象相 互作用可以在壳模型框架下用以描述核子间的相互 作用, 并且在跨度较大的核区内给出与实验相符的 结果.

\section{参考文献}

1 Kuo T T S. Folded-diagram theory of the effective interaction in nuclei, atoms and molecules. Lecture Notes in Physics. Berlin: Springer Verlag, 1990, 364

2 Warburton E K, Brown B A. Effective interactions for the 0p1s0d nuclear shell-model space. Phys Rev C, 1992, 46: 923

3 Wildenthal B H. Empirical strengths of spin operators in nuclei. Prog Part Nucl Phys, 1984, 11: 5-51

4 Brown B A, Richter W A. New “USD” Hamiltonians for the $s d$ shell. Phys Rev C, 2006, 74: 034315

5 Honma M, Otsuka T, Brown B A, et al. Effective interaction for $p f$-shell nuclei. Phys Rev C, 2002, 65: 061301

6 Green I M, Moszkowski S A. Nuclear coupling schemes with a surface delta interaction. Phys Rev B, 1965, 139: 790

7 Sagawa H, Brown B A, Scholten O. Shell-model calculations with a skyrme-type effective interaction. Phys Lett B, 1985, 159: 228-232

8 Dechargé J, Gogny D. Hartree-Fock-Bogolyubov calculations with the D1 effective interaction on spherical nuclei. Phys Rev C, 1980, 21: 1568

9 Berger J F, Girod M, Gogny D. Time-dependent quantum collective dynamics applied to nuclear fission. Comput Phys Commu, 1991, 63: $365-374$

10 Goriely S, Hilaire S, Girod M, et al. First Gogny-Hartree-Fock-Bogoliubov nuclear mass model. Phys Rev lett, 2009, 102: 242501

11 Chung W. Empirical renormalization of shell-model Hamiltonians and magnetic dipole moments of sd-shell nuclei. Doctor Dissertation. East Lansing: Michigan State University, 1976

12 Brody T A, Moshinsky M. Tables of transformation brackets for nuclear shell-model calculations. Nucl Phys A, 1967, 176: 413-432

13 Wong C W, Clement D M. Vector bracket and transformed wave function of a few-body state. Nucl Phys A, 1972, 183: 210-224

14 Lawson R D. Theory of the Nuclear Shell Model. Oxford: Clarendon Press, 1980

15 Heyde K L G. The nuclear shell model. The Nuclear Shell Model. Berlin, Heidelberg: Springer, 1990. 54-135

16 Erkelenz K, Alzetta R, Holinde K. Momentum space calculations and helicity formalism in nuclear physics. Nucl Phys A, 1971, 176: 413-432

17 Gómez J M G, Cerdán J C P, Prieto C. Shell-model description of nuclei with $4 \leqslant A \leqslant 16$ using Skyrme forces. Nucl Phys A, 1993, 551: 451-472

18 Ring P, Schuck P. The Nuclear Many-Body Problem. Berlin, Heidelberg: Springer, 2004

19 Cohen S, Kurath D. Effective interactions for the 1p shell. Nucl Phys, 1965, 73: 1-24

20 National nuclear data center evaluated nuclear structure data file, http://www.nndc.bnl.gov/ensdf/

21 Volya A. Time-dependent approach to the continuum shell model. Phys Rev C, 2009, 79: 044308

22 Hjorth-Jensen M, Kuo T T S, Osnes E. Realistic effective interactions for nuclear systems. Phys Rep, 1995, 261: 125-270 


\title{
Shell-model calculation with density-dependent Gogny interaction
}

\author{
JIANG WeiGuang, HU BaiShan \& XU FuRong* \\ School of Physics, Peking University, Beijing 100871, China \\ * Corresponding author, E-mail: frxu@pku.edu.cn
}

Shell model has been an important and powerful tool for describing the structures of finite nuclei. In shell-model calculations, one of the most important questions is to construct the effective Hamiltonian in the truncated model space. One way is to start from realistic nuclear forces and then use perturbation theory to get the effective interaction. However, these calculations are complicated. If one wants to gain better quantitative descriptions one will have to take the high-order correlations (e.g., three-nucleon force, 3NF) into consideration. High-order correlations make calculations even more complicated and give rise to a significant growth of the model dimension. Another way is to start form an empirical TBMEs which will provide more quantitative results with simpler shell-model calculations. In empirical methods, the TBMEs are usually derived from realistic interactions originally and then are modified by fitting the experimental data coming from nuclear structures(including nuclear binding energies, excitation spectra and transition properties). Effects of the missing high-order correlations (e.g., 3NFs) are assume to be equivalently taken into account by fitting procedure. Yet the fitting can be a troubled process while there are too many TBMEs to be fitted. Meanwhile there will be large uncertainties in evaluating the TBMEs since some of matrix elements (especially for off-diagonal matrix elements) are insensitive to the data fitting. When it come to cross-shell cases, i.e. the model space including two or more major shells, the fitting process will be even more intricate. Not only because the large number of TBMEs to be fitted, but also that it is difficult to obtain the SPEs in such cases. We cannot distinguish the collective core excitations and single-particle excitations because they can get really close for cross-shell cases while the energy for the system is high. To deal with the above problems and to discuss the cross-shell situation properly, in the present work, we introduce the Gogny density-dependent force to study the structure of finite nuclei. The nature of density-dependent interactions is concerned and its application in shell-model is carefully discussed. The Gogny interaction contains totally 14 free parameters. There are several mature sets of the Gogny parameters which are fitted to nuclear structure data determined by mean-field calculations (Hartree-Fock-Bogolyubov). In the present shell-model calculations, we apply the existing mean-field Gogny parameters without refitting. Several Gogny force are tested in which D1S interaction gives the best result. In practice, we need to deal with the density-dependent term of Gogny force in shell-model frame using iteration methods. It is worth mention that, in our method, both two-body matrix elements and single-particle energies are reached by unified Gogny interaction and so are the binding energies. In this paper calculated the spectra, binding energies etc. for $p$-shell and $s d$-shell nuclei and the results are in good agreement with experimental data. Particularly, in the calculation of binding energies for oxygen chain isotopes, the present model can reproduce its neutron drip line which is an important task for nuclear structure study. It is due to the fact that Gogny interaction have consider reasonable three-body effects by its density-dependent term. In conclusion, the Gongy-like phenomenological interactions can describe the properties of $p$-shell and $s d$-shell nuclei and have the potential for further shell-model calculation.

\section{shell-model, effective interaction, Gogny force, two-body matrix element, single particle energy}

doi: 10.1360/N972017-00265 